\title{
Rachel Rosen
}

Book Review: O'Toole, T. and Gale, R. (2013). Political Engagement Amongst Ethnic Minority Young People: Making a difference. Basingstoke, Hampshire: Palgrave Macmillan.

Contesting the thesis that 'ethnic minority' young people ${ }^{1}$ have become politically apathetic and conversely are prone to violent extremism, O'Toole and Gale offer insight into minoritized young people's complex 'grammars of political action' and the socio-spatial relations in which their political subjectivities and activity are entangled.

Drawing on 12 focus groups with 'participatory' organisations and follow-up interviews with 50 individuals, primarily between 16-18-years-old, in Birmingham and Bradford, UK, from 2004-2007, Political Engagement Amongst Ethnic Minority Young People works in two primary directions. First, it examines the contextual and changing nature of minoritized young people's political activity. The focus of Chapter 5, for instance, is on engagements with pluralised, dispersed, and 'participatory' forms of governance characteristic of the research period. Whilst the authors concur with critiques that such governance initiatives can be tokenistic and disciplinary, they advocate for a 'practice-based assessment': in their study, participants were not passively co-opted but operated in unexpected ways, occasionally reworking assumptions, changing remits, and even developing 'autonomous political agendas' (p.118). In one compelling example, members of the Bradford Youth Parliament subverted a council ban on protests again the Iraq war by holding a 'peace walk'. Some suggestions are made about what might have enabled (and constrained) agency, including the ways in which participants may have felt embolden because they were representing youth constituencies and the formal obligations which bound the local council to consult the youth parliament. This offered an important initial response to calls within childhood studies literature to interrogate agency as a possibility rather than a guarantee (Tisdall and Punch 2012). Overall, however, the reader was left wanting to more about: what opened up spaces for agency, diversity in the motivation and forms which such agency took, and the impacts of this agency, including whether it was evaluated as successful by those involved.

\footnotetext{
${ }^{1}$ Surprisingly, the authors leave the terms 'young people' and 'ethnic minority' largely unexamined. Suffice it to say these are highly contested and culturally variant conceptual categories, rather than simple mappings of a given ontological reality. Processual terms such as 'minoritized' or 'generationed' are often utilised to indicate the ways such categories are both produced by and productive of (inequitable) socio-spatial relations.
} 
In Chapters 6-7, O'Toole and Gale argue for the continued salience of group identities formed in part by processes which stigmatise, criminalise, segregate and discriminate against minoritized young people - in motivating political participation. In particular, they note the relationship between rising Islamophobia and increasing role of 'faith identities' in 'animat[ing] political engagements' (p.157). These identities feature centrally in Chapter 8 which shifts the focus to a more overtly spatial discussion primarily, although not uncritically, in reference to scale. Here, O'Toole and Gale make a convincing argument that - in combination with increased global connections through ICT - faith-based political subjectivities, specifically those grounded in the global Muslim umma, led to 'glocal' political engagement which went beyond individual diasporic trajectories.

Less analytic attention, however, was given social class, either in terms of identity or the way socio-spatial relations were (re)configured in the period of study: Was social class viewed as a relevant group identity or used as a reference point for other identities? Was it mobilised in ways which exceed personal identification as the basis for political activity? To a certain extent this relative absence is attributable to the difficulties of operationalising the 'intersectional' approach taken by the authors, where - given the complexities of inequality particular socio-spatial relations will often be premised for analytic purposes. It is questionable, however, the extent to which minoritized young people's experiences can be understood without reference to changing material contexts: indeed, New Labour's policies on 'race' and community cohesion, which form a central backdrop to the narratives in the study, are thoroughly entangled with the 'savage cuts' and deepening class inequalities in the post-crisis British economy (Shain 2013, 79), as well as 'long-standing issues of socioeconomic inequality between ethnic groups' (p.105) which the authors themselves point to. At very least, this indicates the need for further theoretical and methodological work in bringing an intersectional lens to bear in childhood research, including entering into debates about the (im)possibilities of bringing together political-economic and intersectional lines of analysis. One fruitful approach may be to conceptualise intersectionality in terms of sociospatial relations, rather than categorical identities, of power and inequality.

A second direction pursed in the text is an attempt to operationalise broadened conceptions of the political, an idea which finds resonance in much of the emerging children's geographies literature about children and young people's everyday forms of political agency alongside, even beyond, more conventional engagement with government institutions, policies, and electoral processes. Attempts to work with an empirically-situated understanding of the political remains a tension in the book, however: for instance, participants were chosen from groups associated with the researchers' a priori typology of political engagement. The point here is that even beginning with a broader typology of the 
political does not dispense with Kallio and Häkli's $(2010,357)$ argument that in taking seriously the possibility that children and young people engage in ways which exceed conventional, often adult-centric, notions we cannot assume to 'know what politics is before studying it'.

More consequentially, however, the authors seem content with the largely binary contrast in much contemporary literature between political subjectivities which are seen to underpin more conventional politics - involving programmatic, representative and collectivist activities and orientations - and those involved in 'subpolitics' which are seen to be characterised by 'more immediate, personal, direct, hands-on, everyday forms of activism' (p.211) and avoidance of 'immersion... into collective identity movements' (p.91). Yet, as discussed above, their data includes detailed accounts of the salience of group identities in motivating political participation; the ways some participatory groups in the study attempted to develop collective visions and programmes of action; as well as their commitment to mentoring new members into longer-term activities. This data seems to suggest that a more nuanced account of political subjectivities in the contemporary is needed: whilst minoritized young people may not be committed to institutionally-embedded forms of collective activity, and may operate within changing forms and scales of action, neither are their political subjectivities merely a matter of personal choice or fluid, short-termism.

\section{References}

Kallio, Kirsi Pauliina, and Jouni Häkli. 2010. Political geography in childhood. Political Geography 29 (7):357-358.

Shain, Farzana. 2013. Race, nation and education: An overview of British attempts to 'manage diversity' since the 1950s. Education Inquiry 4 (1):63-85.

Tisdall, E. Kay M., and Samantha Punch. 2012. Not so 'new'? Looking critically at childhood studies. Children's Geographies 10 (3):249-264. 